\title{
Selection of Plant Location using Consistent FAHP and Goal Programming Technique
}

\author{
G.Nirmala, G. Uthra
}

\begin{abstract}
Analytic Hierarchy Process (AHP) is one of the effectively used tools for solving Multi Criteria decision making problem. In AHP the decision maker's ambiguity and uncertainty cannot be handled. To solve this, AHP is extended in Fuzzy environment. In this paper a new method of Fuzzy AHP based on multiplicative consistent fuzzy preference relation is introduced. In this method, an iterative algorithm is given to construct comparison matrices from $n(n-1) / 2$ preferences .From these comparison matrices the weight vectors are evaluated by goal programming technique. The validity of this method is checked by applying this it to a solved problem in the literature and it is found that this method yields the same result. Location of a manufacturing plant has a significant impact on the performance of the company as it minimizes the cost and maximizes the use of resource. A manufacturing industry wants to select a location for its new plant. The method proposed in this paper is applied to select the best location out of several alternatives with the real time data.
\end{abstract}

Keywords: Analytic Hierarchy process, Consistency, Fuzzy preference relation, Location selection, Multi criteria Decision making problem

\section{INTRODUCTION}

While constructing a new plant the foremost question to be answered is about the location. The location should be selected in such a way that the cost, time should be minimized. The use of the resources and profit should be maximized. Selection of a plant involves many criteria. So these become Multi Criteria Decision Making (MCDM) problem.

Many approaches have been introduced to solve MCDM problem such as PROMTHEE, ELECTREE, TOPSIS and AHP etc....AHP developed by T.L.Saaty [1] is a widely used approach for decision making problem, in which any decision making problem can be structured into multi-level hierarchical structure. Though AHP has been widely used method, uncertainty, vagueness and ambiguity of human thinking cannot be expressed using AHP. Fuzzy theory introduced by Zadeh [2] is an effective tool to deal with uncertainty and vagueness. So AHP is extended in fuzzy environment, representing the elements of the comparison matrix by fuzzy numbers.
FAHP was first studied by VaanLaarhoven and Pedrycz [3]. In their paper they introduced logarithmic least square method for deriving priorities. Later C.G.E.Boender et al [4] made a correction on normalization procedure of formers. L.Mikhailov [5] introduced an alpha-cut method to derive priorities from fuzzy pairwise comparison matrices whose elements are triangular fuzzy numbers. Chang [6] used extent analysis to get weight vectors from comparison matrices. This method has been applied widely by many authors in different fields. But Wang Luo and Huo [7] proved by showing some examples that extent analysis method cannot estimate the true weights and has led to quiet a number of misapplications in the literature. J.J.Buckely [8] used fuzzy ratios in place of exact ratios in hierarchical analysis and used Geometric mean method to derive priorities. The consistence of the comparison matrices are not established in all the above methods. This is the main disadvantage of all the methods. Wang and Chen [9] introduced linear goal programming method to derive priorities and applied to new product screening. Even though this method ensures the consistency, the calculations used in this method are difficult.

Location selection problem has been solved by many authors using several methods like Fuzzy MCDM, Fuzzy TOPSIS, AHP, ANP, Fuzzy AHP, Delphi-AHPVIKOR methodology etc. Apple [10], Moore [11] gave the list of factors to be considered while selecting a plant location. Yong [12] used Fuzzy TOPSIS method based on linguistic terms for location selection problem. Farahani and Asgari [13] used TOPSIS method to find the supportive centres in military logistic system. Onut and Soner [14] a Fuzzy TOPSIS methodology integrated with AHP to select a suitable site for transhipment of solid waste. D.B Mahalik [15] used AHP with GRA methodology to select a suitable site. B.Vahdani et al [16] used three step Methodology consist of Delphi-AHP-VIKOR to select best location.

In this paper to select a location for a new plant of a manufacturing company, a new method of FAHP is introduced. The novelty of this method is construction of complete consistent comparison matrices using only $\mathrm{n}-1$ values. Goal programming technique is used to derive priorities from the comparison matrices. To do so, this paper is structured as follows.

In the initial section the problem is introduced and the literature survey is given. Section -1 explains the methodology used in this paper. In the next section, to check the validity of the proposed method, it is applied to a solved problem in the literature. Section-3 gives the case analysis. In Final section conclusion is given.
Revised Manuscript Received on December 5, 2019.

G.Nirmala, Assistant Professor, Dept. of Mathematics, Sri SaiRam Engg College, Chennai-600040, Tamilnadu. nirmala.math@ sairam.edu.in

G. Uthra, Assistant Professor, Dept. of Mathematics, Pachiyappa's College, Chennai-600030, Tamilnadu.

uthragopalsamy@yahoo.co.in 


\section{METHODOLGY}

\subsection{Fuzzy Analytic Hierarchy Process:}

In AHP the consistency of the comparison matrix is an important issue. Inconsistency leads to unreliable solution. To focus on consistency the preference relations are introduced.

Among these Multiplicative preference relation by Saaty [1], Fuzzy Preference Relation (FPR) by Orvolosky [18] have received much attention. The definition of FPR is given as follows:

\section{Def: 1}

Let $X=\{X 1, X 2, \ldots \ldots ., X n\}$ be a fixed set, then $R$ $=\left(r_{i j}\right)_{n \times n}$ is called fuzzy Preference relation with the condition $r_{i j} \geq 0, r_{i j}+r_{j i}=1, i, j=1,2, \ldots . ., n$ where $r_{i j}$ denotes the degree that thealternative $x_{i}$ is prior to the alternative $\mathrm{x}_{\mathrm{j}}$.

To establish a comparison matrix with $\mathrm{n}$ criteria it requires $\frac{n(n-1)}{2}$ comparisons. As the number of criteria increases, the matrices become inconsistent. To avoid this, Herrera-Videma [19] introduced an algorithm

based on additive transitivity property to construct a consistent comparison matrix as follows.

In this paper, consistent matrix is constructed based on multiplicative transitivity property. The definition of Multiplicative Transitivity Tanino [20] and algorithm to construct a consistent comparison matrix is as follows:

Def: 2

FPR $\quad \mathrm{R}=\left(\mathrm{r}_{\mathrm{ij}}\right)_{\mathrm{nxn}}$ is called a Multiplicative Consistent preference relation, if it satisfies the multiplicative transitivity property:

$$
r_{i j} r_{j k} r_{k i}=r_{j i} r_{k j} r_{i k} i, j, k=1,2, \ldots, n
$$

where $r_{i j} \geq 0$.

By simple calculations it can be shown that

$$
r_{i j}=\frac{r_{i k} r_{k j}}{r_{i k} r_{k j}+\left(1-r_{i k}\right)\left(1-r_{k j}\right)}
$$

H.Xia and Z.Xu [21] proved that the above equation is equivalent to

$$
r_{i j}=\frac{\sqrt[j-i-1]{\prod_{t=i+1}^{j-1} r_{i t} r_{t j}}}{\sqrt[j-i-1]{\prod_{t=i+1}^{j-1} r_{i t} r_{t j}}+\sqrt[j-i-1]{\prod_{t=i+1}^{j-1}\left(1-r_{i t}\right)\left(1-r_{t j}\right)}}
$$

\section{Algorithm: 2.1}

The method to construct a consistent FPR for a set $X=\left\{x_{1}, x_{2}, \ldots, x_{n}\right\}$ as follows:

Step: 1 Get $\mathrm{n}-1$ preference values $\left\{r_{12}, r_{23}, . ., r_{n(n-1)}\right\}$

from decision maker and $r_{i i}=0.5$

Step: 2 Find $r_{i j}$ for $\mathrm{j}=\mathrm{i}+2$ by using the formula

Step: 3 Find $r_{i j}$ for $\mathrm{j}>\mathrm{i}+2$ by using the formula

Step: 4 find for all $r_{j i}=1-r_{i j}$ for all $j \geq i$

\section{Example:}

Consider the following matrix on four criteria.

$$
\left(\begin{array}{cccc}
0.5 & 0.1 & x & x \\
x & 0.5 & 0.8 & x \\
x & x & 0.5 & 0.9 \\
x & x & x & 0.5
\end{array}\right)
$$

The values $\left\{r_{12}, r_{23}, r_{34}\right\}$ are evaluated by decision maker. $r_{13}=0.308, r_{24}=0.974$ are got by equation (1). $r_{14}=0.6611$ are got by equation (2).Remaining elements are calculated by $r_{j i}=1-r_{i j}$.

So we get $\begin{aligned} r_{21}=0.9, r_{31}=0.698, r_{32}=0.2, \\ r_{41}=0.3398, r_{42}=0.027, r_{43}=0.1\end{aligned}$

\subsection{Goal programming Technique:}

Goal programming is a branch of multi objective programming which is started from the work of Charnes and Cooper [22] and further developed by many others. It is used as a technique to find satisfying solution to MCDM problem.

Tsechulin and Jacques [23] formulated a goal programming to derive priority vectors from comparison matrices in AHP. Fuzzy AHP combined with goal programming technique are used by Shaw et al [24], Srivrikaya et al [25] and many others.

A simple goal programming model for deriving priority weights from fuzzy comparison matrices as follows:

$$
\begin{aligned}
& \min =\sum \sum\left(d_{i j}^{+}+d_{i j}^{-}\right) \quad \text { for } i, j=1,2, \ldots, n \\
& \text { subject to } \\
& w_{i}\left(a_{i j}-1\right)+w_{i} a_{i j}+d_{i j}^{+}-d_{i j}^{-}=0 ; \\
& \sum_{i=1}^{n} w_{i}=1 \\
& w_{i} \geq 0 ; d_{i j}^{+} \geq 0 ; d_{i j}^{-} \geq 0 ;
\end{aligned}
$$

\section{VALIDATION}

To check the reliability, of the new method of FAHP and goal programming technique proposed in the paper is applied to a problem with the same data authored by Kong, Liu [26].In that paper the author evaluated the success factors of e-commerce.

The hierarchical structure of the problem is given below: 


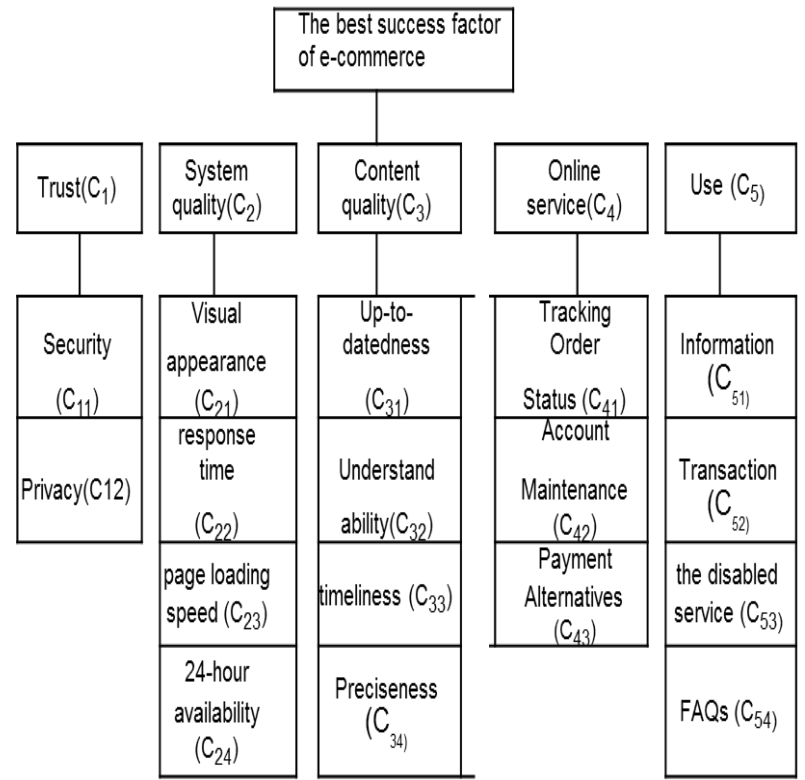

Fig 1Hierarchical structure of the problem

For the comparison matrices the authors used Fuzzy numbers in the interval $[0,1]$. The criteria comparison matrix is given in Table-1

Table-1Criteria comparison matrix

\begin{tabular}{llllll} 
& C1 & C2 & C3 & C4 & C5 \\
\hline C1 & 0.5 & 0.8 & 0.7 & 0.5 & 0.9 \\
\hline C2 & 0.2 & 0.5 & 0.4 & 0.1 & 0.4 \\
\hline C3 & 0.3 & 0.6 & 0.5 & 0.3 & 0.7 \\
\hline C4 & 0.5 & 0.9 & 0.7 & 0.5 & 0.7 \\
\hline C5 & 0.1 & 0.6 & 0.3 & 0.3 & 0.5
\end{tabular}

Taking $r_{12}, r_{23}, r_{34}, r_{45}$ values from the table and evaluating other values using our procedure we get the matrix.

Table-2Criteria comparison matric by our method

\begin{tabular}{llllll} 
& C1 & C2 & C3 & C4 & C5 \\
\hline C1 & 0.5 & 0.8 & 0.7272 & 0.64 & 0.76 \\
\hline C2 & 0.2 & 0.5 & 0.4 & 0.22 & 0.4 \\
\hline C3 & 0.2727 & 0.6 & 0.5 & 0.3 & 0.7 \\
\hline C4 & 0.3642 & 0.778 & 0.7 & 0.5 & 0.7 \\
\hline C5 & 0.246 & 0.6 & 0.5 & 0.3 & 0.5
\end{tabular}

By using goal programming technique the weight vectors derived from the above matrix are $(0.348,0.08$, $0.131,0.31$, and 0.13).Likewise all other matrices are constructed and weight vectors are evaluated. The results from this method and the method in Kong, Liu are compared and given in following table.

Table-3Comparison results

\begin{tabular}{|c|c|c|c|c|c|c|c|}
\hline \multicolumn{8}{|c|}{ Evaluating success factors of e-commerce } \\
\hline \multirow[t]{3}{*}{ Criteria } & \multirow{3}{*}{$\begin{array}{c}\text { Priority } \\
\text { By the } \\
\text { method } \\
\text { in Kong, } \\
\text { Liu } \\
\\
0.37\end{array}$} & \multirow{3}{*}{$\begin{array}{r}\begin{array}{l}\text { By our } \\
\text { method }\end{array} \\
\\
\\
0.34 \\
\end{array}$} & \multirow{2}{*}{$\begin{array}{c}\begin{array}{c}\text { Sub- } \\
\text { criteria }\end{array} \\
\mathrm{C}_{11} \\
\end{array}$} & \multirow{2}{*}{$\begin{array}{c}\begin{array}{c}\text { Priorit } \\
\text { crit } \\
\text { By the } \\
\text { method } \\
\text { in Kong, } \\
\text { Liu }\end{array} \\
0.7\end{array}$} & \multirow{2}{*}{$\begin{array}{c}\begin{array}{c}\text { By our } \\
\text { method }\end{array} \\
0.7 \\
\end{array}$} & \multicolumn{2}{|c|}{$\begin{array}{c}\text { Final priority of sub } \\
\text { criteria }\end{array}$} \\
\hline & & & & & & 0.25 & 0.26 \\
\hline & & & $\mathrm{C}_{12}$ & 0.3 & 0.3 & 0.1 & 0.11 \\
\hline \multirow[b]{4}{*}{$C_{2}$} & \multirow[b]{4}{*}{0.06} & \multirow[b]{4}{*}{0.08} & $\mathrm{C}_{21}$ & 0.28 & 0.26 & 0.02 & 0.01 \\
\hline & & & $\mathrm{C}_{22}$ & 0.18 & 0.17 & 0.01 & 0.01 \\
\hline & & & $\mathrm{C}_{23}$ & 0.11 & 0.11 & 0.01 & 0.01 \\
\hline & & & $\mathrm{C}_{24}$ & 0.43 & 0.46 & 0.04 & 0.03 \\
\hline \multirow[b]{4}{*}{$C_{3}$} & \multirow[b]{4}{*}{0.15} & \multirow[b]{4}{*}{0.13} & $\mathrm{C}_{31}$ & 0.15 & 0.14 & 0.02 & 0.02 \\
\hline & & & $\mathrm{C}_{32}$ & 0.5 & 0.55 & 0.07 & 0.07 \\
\hline & & & $\mathrm{C}_{33}$ & 0.46 & 0.06 & 0.01 & 0.01 \\
\hline & & & $\mathrm{C}_{34}$ & 0.29 & 0.25 & 0.03 & 0.04 \\
\hline \multirow[b]{3}{*}{$C_{4}$} & \multirow[b]{3}{*}{0.34} & \multirow[b]{3}{*}{0.31} & $\mathrm{C}_{41}$ & 0.47 & 0.48 & 0.15 & 0.16 \\
\hline & & & $\mathrm{C}_{42}$ & 0.2 & 0.2 & 0.06 & 0.07 \\
\hline & & & $\mathrm{C}_{43}$ & 0.31 & 0.31 & 0.09 & 0.11 \\
\hline \multirow[b]{3}{*}{$C_{5}$} & \multirow[b]{3}{*}{0.06} & \multirow[b]{3}{*}{0.13} & $\mathrm{C}_{51}$ & 0.19 & 0.11 & 0.01 & 0.01 \\
\hline & & & $\mathrm{C}_{52}$ & 0.43 & 0.33 & 0.04 & 0.02 \\
\hline & & & $\mathrm{C}_{53}$ & 0.16 & 0.22 & 0.02 & \\
\hline
\end{tabular}




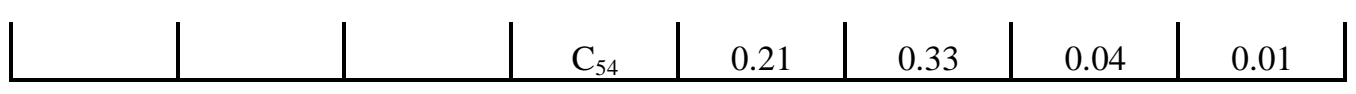

From this it can be concluded that our method yields the same ranking as that of the paper. Hence our procedure is the reliable. Because of the given automatic algorithm the Decision Maker's work is reduced .This is the main advantage of this method.

\section{CASE ANALYSIS}

In this study, a manufacturing industry $\mathrm{X}$ based on Chennai wants to establish its new plant at the options $A_{1}$, $A_{2}, A_{3}$.Discussing with top level managers of the company who are the decision maker's for this problem the criteria are selected. Criteria and Sub criteria are given in the following table.

Table-4Criteria and sub criteria table

\begin{tabular}{|c|c|}
\hline Criteria & Sub Criteria \\
\hline \multirow[t]{4}{*}{ Cost (C) } & Initial Investment Cost $\left(\mathrm{C}_{1}\right)$ \\
\hline & Maintenance cost $\left(\mathrm{C}_{2}\right)$ \\
\hline & Transportation cost $\left(\mathrm{C}_{3}\right)$ \\
\hline & Labor cost $\left(\mathrm{C}_{4}\right)$ \\
\hline \multirow{4}{*}{$\begin{array}{l}\text { Transport } \\
\text { facility }(\mathrm{T})\end{array}$} & Proximity to urban $\operatorname{areas}\left(\mathrm{T}_{1}\right)$ \\
\hline & $\begin{array}{lll}\text { Proximity } & \text { to } & \text { public } \\
\operatorname{transport}\left(\mathrm{T}_{2}\right) & & \\
\end{array}$ \\
\hline & Proximity to warehouse $\left(\mathrm{T}_{3}\right)$ \\
\hline & Customs $\left(\mathrm{T}_{4}\right)$ \\
\hline \multirow{4}{*}{$\begin{array}{l}\text { Environmental } \\
\text { Issue (E) }\end{array}$} & Drainage System $\left(\mathrm{E}_{1}\right)$ \\
\hline & Regulations $\left(\mathrm{E}_{2}\right)$ \\
\hline & $\begin{array}{l}\text { Proximity to energy resources } \\
\text { like water, } \\
\text { fuel and Natural gas(E3) }\end{array}$ \\
\hline & Expansion Possibility(E4) \\
\hline \multirow[t]{4}{*}{$\begin{array}{l}\text { Work force } \\
\text { (W) }\end{array}$} & $\begin{array}{l}\text { Availability of Labor force } \\
\text { (W1) }\end{array}$ \\
\hline & $\begin{array}{l}\text { Availability of Medical } \\
\text { facility for work force(W2) }\end{array}$ \\
\hline & Skilled Labor (W3) \\
\hline & $\begin{array}{l}\text { Availability of Transportation } \\
\text { facility to the workforce(W4) }\end{array}$ \\
\hline \multirow[t]{2}{*}{$\begin{array}{l}\text { Political } \\
\text { Situation (P) }\end{array}$} & $\begin{array}{l}\text { Support from } \text { Government } \\
\text { (P1) }\end{array}$ \\
\hline & Subsidiary (P2) \\
\hline
\end{tabular}

Since this problem has multiple criteria, this can be taken as MCDM problem. The proposed method in this paper is applied to the problem of location selection. The decision makers are asked to fill the comparison matrix with the help of judgement scale which is given in the following table.
Table-5 Judgement scale for FAHP

\begin{tabular}{|l|r|}
\hline Verbal term & Scale values \\
\hline Extremely not preferred & 0.1 \\
\hline $\begin{array}{l}\text { Very strongly not } \\
\text { preferred }\end{array}$ & 0.2 \\
\hline Strongly nor preferred & 0.3 \\
\hline Moderately not preferred & 0.4 \\
\hline Equally preferred & 0.5 \\
\hline Moderately preferred & 0.6 \\
\hline Strongly preferred & 0.7 \\
\hline Very strongly preferred & 0.8 \\
\hline Extremely preferred & 0.9 \\
\hline \multicolumn{2}{|c|}{ To construct the comparison matrices, the }
\end{tabular}
preference values for the consecutive elements should be filled by decision makers. Criteria comparison matrix is given as example.

Table-6 Comparison matrix

\begin{tabular}{llllll} 
& $\mathrm{C}$ & $\mathrm{T}$ & $\mathrm{E}$ & $\mathrm{W}$ & $\mathrm{P}$ \\
\hline $\mathrm{C}$ & 0.5 & $\mathrm{X}$ & & & \\
\hline $\mathrm{T}$ & & 0.5 & $\mathrm{X}$ & & \\
\hline $\mathrm{E}$ & & & 0.5 & $\mathrm{x}$ & \\
\hline $\mathrm{W}$ & & & & 0.5 & $\mathrm{X}$ \\
\hline $\mathrm{P}$ & & & & & 0.5
\end{tabular}

Here $\mathrm{x}$ marked cells are filled by Decision maker. Remaining values are evaluated by procedure explained in this paper. The constructed comparison matrix is given as follows.

Table-7Consistent comparison matrix

\begin{tabular}{llllll} 
& $\mathrm{C}$ & $\mathrm{T}$ & $\mathrm{E}$ & $\mathrm{W}$ & $\mathrm{P}$ \\
\hline $\mathrm{C}$ & 0.5 & 0.55 & 0.64 & 0.92 & 0.93 \\
\hline $\mathrm{T}$ & 0.45 & 0.5 & 0.6 & 0.89 & 0.91 \\
\hline $\mathrm{E}$ & 0.36 & 0.4 & 0.5 & 0.85 & 0.87 \\
\hline $\mathrm{W}$ & 0.08 & 0.11 & 0.15 & 0.5 & 0.55 \\
\hline $\mathrm{P}$ & 0.07 & 0.09 & 0.13 & 0.45 & 0.5
\end{tabular}

From this matrix weight vectors are derived by Goal Programming technique.

Solution of these equations are :

$\mathrm{W}_{1}=0.3935749$

$\mathrm{W}_{2}=0.3220159$

$\mathrm{W}_{3}=0.2146772$

$\mathrm{W} 4=0.0379$

$\mathrm{W} 5=0.03$

Likewise weight vectors for all criteria and sub criteria are calculated are listed in the following table. 
Table-8Alternative weights table

\begin{tabular}{|c|c|c|c|c|c|c|c|c|c|}
\hline \multirow[t]{2}{*}{ Criteria } & \multirow{2}{*}{$\begin{array}{l}\text { Criteria } \\
\text { weights }\end{array}$} & \multirow{2}{*}{$\begin{array}{l}\text { Sub } \\
\text { criteria }\end{array}$} & \multirow{2}{*}{$\begin{array}{l}\text { Weights } \\
\text { of sub } \\
\text { criteria }\end{array}$} & \multicolumn{3}{|c|}{ Local weights } & \multicolumn{3}{|c|}{ Global weights } \\
\hline & & & & $\overline{A_{1}}$ & $\mathrm{~A}_{2}$ & $\overline{A_{3}}$ & $\overline{A_{1}}$ & $\mathrm{~A}_{2}$ & $\mathrm{~A}_{3}$ \\
\hline \multirow[t]{4}{*}{$\mathrm{C}$} & 0.395 & $\mathrm{C}_{1}$ & 0.64 & 0.74 & 0.16 & 0.1 & 0.03 & 0.007 & 0.0044 \\
\hline & & $\mathrm{C}_{2}$ & 0.18 & 0.7 & 0.17 & 0.13 & 0.08 & 0.002 & 0.0016 \\
\hline & & $\overline{\mathrm{C}_{3}}$ & 0.11 & 0.32 & 0.42 & 0.26 & 0 & 0.003 & 0.002 \\
\hline & & $\mathrm{C}_{4}$ & 0.07 & 0.48 & 0.22 & 0.3 & 0 & 0.001 & 0.0015 \\
\hline \multicolumn{4}{|c|}{ Overall weights of Cost } & 2.24 & 0.97 & 0.79 & 0.04 & 0.014 & 0.0096 \\
\hline \multirow[t]{4}{*}{$\mathrm{T}$} & 0.322 & $\mathrm{~T}_{1}$ & 0.49 & 0.31 & 0.41 & 0.28 & 0.03 & 0.052 & 0.036 \\
\hline & & $\mathrm{T}_{2}$ & 0.21 & 0.33 & 0.38 & 0.29 & 0.01 & 0.02 & 0.0158 \\
\hline & & $\mathrm{T}_{3}$ & 0.13 & 0.63 & 0.2 & 0.17 & 0.02 & 0.006 & 0.0057 \\
\hline & & $\overline{T_{4}}$ & 0.07 & 0.59 & 0.23 & 0.18 & 0.01 & 0.004 & 0.0033 \\
\hline \multicolumn{4}{|c|}{ Overall weights of Transport facility } & 2.82 & 1.91 & 1.27 & 0.1 & 0.092 & 0.0648 \\
\hline \multirow[t]{4}{*}{$\mathrm{E}$} & 0.215 & $\mathrm{E}_{1}$ & 0.19 & 0.52 & 0.15 & 0.33 & 0.01 & 0.005 & 0.0113 \\
\hline & & $\mathrm{E}_{2}$ & 0.15 & 0.16 & 0.33 & 0.51 & 0.11 & 0.008 & 0.0137 \\
\hline & & $\overline{E_{3}}$ & 0.26 & 0.54 & 0.22 & 0.24 & 0.02 & 0.01 & 0.011 \\
\hline & & $\overline{E_{4}}$ & 0.19 & 0.15 & 0.25 & 0.6 & 0 & 0.008 & 0.0205 \\
\hline \multicolumn{4}{|c|}{ Overall weights of Environmental facility } & 1.93 & 2.06 & 2.01 & 0.07 & 0.074 & 0.0681 \\
\hline \multirow[t]{4}{*}{$\mathrm{W}$} & 0.038 & $\mathrm{~W}_{1}$ & 0.5 & 0.32 & 0.52 & 0.16 & 0.06 & 0.104 & 0.032 \\
\hline & & $\mathrm{W}_{2}$ & 0.21 & 0.38 & 0.32 & 0.3 & 0.03 & 0.026 & 0.0252 \\
\hline & & $\mathrm{W}_{3}$ & 0.12 & 0.33 & 0.5 & 0.17 & 0.01 & 0.024 & 0.0081 \\
\hline & & $\mathrm{W}_{4}$ & 0.12 & 0.29 & 0.61 & 0.1 & 0.01 & 0.029 & 0.0048 \\
\hline \multicolumn{4}{|c|}{ Overall weights of workforce } & 1.66 & 2.41 & 0.93 & 0.13 & 0.193 & 0.0741 \\
\hline \multirow[t]{2}{*}{$\mathrm{P}$} & 0.032 & $\mathrm{P}_{1}$ & 0.12 & 0.37 & 0.33 & $\overline{0.3}$ & 0 & 0.001 & 0.0018 \\
\hline & & $\mathrm{P}_{2}$ & 0.12 & 0.6 & 0.22 & 0.18 & 0 & 0.001 & 0.001 \\
\hline \multicolumn{4}{|c|}{ Overall weights of Political situation } & & 2.79 & 1.27 & 0.94 & 0.028 & 0.0136 \\
\hline \multicolumn{7}{|c|}{ Overall priority } & 0.39 & 0.41 & 0.23 \\
\hline \multicolumn{7}{|c|}{ Alternatives ranking } & 2 & 1 & 3 \\
\hline
\end{tabular}

The final weight vectors for the alternatives are $\mathrm{A}_{1}=0.395 ; \mathrm{A}_{2}=0.409 ; \mathrm{A}_{3}=0.229 ;$ from this it can be concluded that second alternative is the best one.

\section{CONCLUSION}

For a manufacturing industry, location selection is an important issue which depends on several criteria and priority of Decision maker. Since it involves several criteria it can be handled effectively by AHP. Since Goal programming method is used to find the weight vectors, the resultant weight vectors are accurate. Because of the given automatic algorithm to construct the comparison matrix the work of Decision maker is reduced. The validity of this method is also checked. It is found that this method is one of the best and simple method. This method can also be used for other decision making problems.

\section{REFERENCES}

1. Saaty. T.L. The Analytic Hierarchy process: Planning, priority setting, Resource Allocation, 1980 Mc Graw-Hill, London.

2. Zadeh LA.Fuzzy sets,(1965) Information control. 8: 338-353
3. Van Laarhoven. P.J.M. and Pedrycz. W. A Fuzzy extension of Saaty's priority theory, (1983),Fuzzy sets and system.vol.11, pp 229-241

4. Boender.C.G.E, Graan. J.G.De and Lootsman.F.A. Multi Criteria Decision Analysis with pairwise comparison,(1989), Fuzzy sets and system, volume 29, pp 133-143.

5. Mikhailov .L. Deriving priorities from fuzzy pairwise comparison judgments, (2003) Fuzzy sets and systems 134, 365-385

6. Chang.D.Y. Applications of the extent analysis method on the Fuzzy AHP, European Journal of Operations Research., (1996)vol 95,pp 649-655.

7. Y.M.wang,Y.Luo.Z.Hua On the extent analysis method for Fuzzy AHP and its applications, European Journal of Operational Research, (2008)186, 735-747. DOI:10.1016/j.ijar.2008.04.004

8. Buckely. J.J. Fuzzy Hierarchical Analysis, Fuzzy sets and system, (1985),vol 17, pp 233-247.

9. Ying-Ming Wang, Ying Luo, Zhongsheng Hua On the extent analysis method for fuzzy AHP and its applications, European Journal of Operational Research (2008),,186, 735-747.

10. Apple .J.M..Plant Layout and Material Handling, (1977),Wiley,Newyork.

11. Moore.J.M. Plant Layout and Design.:McMillan New York. (1962).

12. Yong.D,Plant location selection based on Fuzzy TOPSIS, International journal of Advance Manufacturing Technology, (2006),Vol,28 pp 839-844. 
13. Farahani. R.Z and Asgari.N. Combination of MCDM and covering techniques in a Hierarchical Model for Facility Location: A case study, European Journal of Operational Research, 1976.pp.18391858.

14. Onut.S and Soner.S Transhipment Site Selection using the AHP and TOPSIS Approaches under Fuzzy Environment. Waste Management, 2008,28, pp: 1552-1559

15. Debendra Kumar Mahalik Selection of a plant site: A Multi Criteria Decision Making Using AHP and GRA, Journal of Supply chain Management systems, (2012), volume 1,Issue 4,October

16. Vahdani .B, mousavi S.M.and Tavakkoli, Moghaddam, Plant Location Selection by using a Three-step Methodology: DelphiAHP-VIKOR, World Academy of Science, Engineering and Technology. International Journal of Mechanical, Aerospace, industrial, Mechatronic and Manufacturing Engineering , (2013),Vol: 7, No: 6

17. Orlovsky. S.A. Decision making with a Fuzzy preference relation, Fuzzy sets and systems, (1978), 1, 155-167.

18. Herrera-Videma.E, Herrera, Chiclana.F, Luque.M Some Issues on Consistency of Fuzzy Preference Relations. European Journal of Operational Research, (2004)154(1), 98-109.

19. Tanino, T. Fuzzy preference orderings in group decision making. Fuzzy Sets System, (1984),12: 117-131

20. M.Xia, Z.Xu On consensus in Group Decision Making Based on Fuzzy Preference Relation ,Consensual Process, STUDFUZZ 267, (2011),pp:263-287,Springer-Verlang Berlin ,Heidelberg.

21. Charnes.A and Cooper W.W. Goal Programming and Multiple Objectives Optimizations. European Journal of Operational Research (1977), 1: pp. 39-54.

22. Tscheulin, D.K. and J.M. Jacques, Goal Programming Approaches for Priorities in Saaty's Analytic Hierarchy Process (AHP).Belgian Journal of operations Research, statistics and Computer science, Vol. 36, No.4, 1996, 189-203

23. Srivrikaya,Fuzzy AHP-Goal Programming approach for supplier selection, Research in Logistics, 2015, Vol. 5, No. 3, pp. 271-285.

24. Shaw et al Supplier selection using fuzzy AHP and fuzzy multiobjective linear programming for developing low carbon supply chain, Expert Systems with Applications ,2012 .39(9):8182-8192

25. Feng kong, Hongyan Liu Applying FAHP to evaluate Success factors of e-commerce, International Journal of Information and systems science,2003, Volume1,Number 3-4,Pages 406-412 